\title{
PERHITUNGAN CADANGAN HIDROKARBON FORMASI TALANG AKAR MENGGUNAKAN ANALISIS PETROFISIKA DAN SEISMIK INVERSI $A I$ DENGAN PENDEKATAN MAP ALGEBRA PADA LAPANGAN BISMA, CEKUNGAN SUMATERA SELATAN
}

\author{
Egi Ramdhani ${ }^{* 1}$, Ordas Deanto1, Karyanto $^{1}$, Nanang Yulianto ${ }^{2}$ \\ ${ }^{1}$ Jurusan Teknik Geofisika, Universitas Lampung \\ Jl. Prof. Dr. Soeamtri Brodjonegoro No.1, Bandar Lampung 35145 \\ ${ }^{2}$ PT Pertamina EP Asset 2 \\ Jurusan Teknik Geofisika, FT UNILA \\ e-mail: *1egiramdhanim@gmail.com
}

\begin{abstract}
ABSTRAK
Sebagai salah satu lapangan dengan prospek hidrokarbon potensial, Lapangan Bisma, yang merupakan bagian dari Cekungan Sumatera Selatan, dapat dievaluasi guna memetakan akumulasi hidrokarbon dan total cadangannya. Analisis petrofisika merupakan metode analitik data untuk evaluasi formasi yang sensitif terhadap perubahan vertikal. Output utama analisis ini adalah kompilasi nilai properti yang berguna dalam penentuan kualitas reservoar. Seismik inversi akustik impedan merupakan metode yang dapat digunakan dalam memetakan sebaran zona poros yang bertindak sebagai reservoar hidrokarbon. Melalui inversi, dapat dihasilkan peta sebaran zona poros menggunakan interpretasi gabungan antara peta $A I$, densitas dan Pwave. Map algebra merupakan metode kalkulasi yang melibatkan peta sebagai input utamanya. Metode ini memungkinkan kita melakukan operasi aritmatik pada peta dengan jumlah grid yang sama. Menggunakan tiga metode tersebut, dilakukan perhitungan cadangan hidrokarbon lapangan Bisma. Hasil analisis petrofisika mengindikasikan zona target merupakan zona prospek minyak pada dua lapisan utama yakni S dan W3. Sedangkan hasil analisis seismik inversi menyatakan sebaran zona poros berkisar pada rentang $A I 7400-9315 \mathrm{~m} / \mathrm{s} * \mathrm{~g} / \mathrm{cc}$. Dilakukan penyebaran nilai porositas efektif, $s w$ dan isopach dengan guide hasil picking horizon dan inversi seismik $A I$ serta dilakukan perhitungan cadangan. Lapisan S mengakumulasi 21.1 juta barrel minyak dan lapisan W3 mengakumulasi 50.2 juta barrel. Hasil didapatkan setelah mengaplikasikan persamaan Original Oil in Place (OOIP) pada peta sebaran properti dengan pendekatan map algebra.
\end{abstract}

\begin{abstract}
As a potential field in hydrocarbon prospect, Bisma field, the part of south Sumatra basin, can be evaluated in order to mapping the hydrocarbon accumulation and total reserve calculation purpose. Petrophysical analysis is an analytic method to evaluate the formation which sensitive with vertical contrast. Main output of this analysis is the compilation of some property value that useful on reservoir quality justification. Seismic acoustic impedance inversion is a method that can be used to define the distribution of porous zone as a hydrocarbon reservoir. This inversion result is the distribution of prospect area map by using combination of interpretation in AI map, density map and P-wave map. Map algebra is a calculation method that used to map that has the same grid number. By using those three methods, the reserve of hydrocarbon accumulation on Bisma field can be calculated. Petrophysical analysis results the indication of hydrocarbon in target zone is oil on two main layer, $\mathrm{S}$ and $\mathrm{W} 3$. Meanwhile, seismic inversion interpreting the distribution of porous zone is between 7400 - $9315 \mathrm{~m} / \mathrm{s}^{*} \mathrm{gr} / \mathrm{cc}$ in AI value context. Then, the effective porosity, $\mathrm{Sw}$ value and isopach are spread laterally using picked horizon and seismic acoustic impedance result as a guide, also, calculating the reserve. Layer $\mathrm{S}$ accumulating 21.1 million barrel oil and W3 accumulating 50.2 million barrel oil. This value resulted by aplicating Original Oil in Place (OOIP) equation on property map with map algebra approachment.
\end{abstract}

Keywords - Talang Akar Formation, Petrophysical Analysis, Acoustic Impedance Inversion, Map Algebra, and Original Oil in Place (OOIP) 


\section{PENDAHULUAN}

Minyak dan gas bumi (migas) merupakan komoditas strategis bagi Indonesia. Selain menyediakan pasokan energi, migas juga menjadi kontributor utama penerimaan negara. Tidak heran jika sektor hulu migas dituntut untuk terus meningkatkan produksi migas nasional walaupun berdasarkan data SKK Migas pada 2015 diketahui kesenjangan produksi dan konsumsi migas di indonesia cukup tinggi. Namun, dibalik tuntutan yang tinggi tersebut, banyak yang belum paham bahwa cadangan migas tidak serta merta ditemukan. Perlu kegiatan pencarian cadangan migas, atau eksplorasi yang bertahun-tahun, sampai suatu cadangan migas ditemukan. Salah satu metode yang baik untuk digunakan dalam eksplorasi migas yaitu metode seismik. Metode seismik yang sering digunakan dalam menggambarkan keadaan bawah permukaan yaitu metode seismik inversi. Untuk menentukan kalkulasi cadangan, dapat digunakan metode petrofisika dengan perhitungan cadangan menggunakan persamaan original oil in place $(O O I P)$.

Metode seismik inversi merupakan teknik inversi berupa suatu pendekatan keadaan geologi secara maju ke depan (fordward modelling), metode ini dapat memberikan hasil penampakan geologi bawah permukaan sehingga dapat diidentifikasi karakter dan pola penyebaran reservoar di daerah target berupa interpretasi geologi, litologi dan fluida serta batas lapisan petrofisika bawah permukaan (Sukmono, 2000). Dalam studi kali ini metode inversi yang digunakan adalah Impedansi Akustik.

Petrofisika pada dasarnya
merupakan suatu metode analisis menggunakan data sumur (log data) dalam proses interpretasinya. Metode ini memanfaatkan besaran-besaran fisis hasil pengukuran logging untuk menghitung nilai properti suatu batuan menggunakan persamaan-persamaan tertentu. Kombinasi antara kedua metode diatas dapat diaplikasikan dalam perhitungan cadangan memanfaatkan persamaan original oil in place dengan pendekatan map algebra yakni operasi kalkulasi yang melibatkan peta sebagai input utamanya.

\section{TINJAUAN PUSTAKA}

Cekungan Sumatera Selatan terletak memanjang berarah BaratlautTenggara di bagian selatan Pulau Sumatera. Luas cekungan ini sekitar $85,670 \mathrm{~km}^{2}$ dan terdiri atas $2 \mathrm{sub}-$ cekungan yaitu: sub-cekungan Jambi berarah Timurlaut-Baratdaya sedangkan sub-cekungan Palembang berarah UtaraBaratlaut-Selatan-Tenggara dan di antara keduanya dipisahkan oleh sesar normal Timurlaut-Baratdaya. Cekungan Sumatera Selatan ini berbentuk tidak simetris, di bagian Pegunungan Tigapuluh dan Pegunungan Duabelas, sedangkan di sebelah Timur dibatasi oleh Pulau-pulau Bangka-Bilton dan di sebelah Selatan dibatasi oleh Tinggian Lampung.

Gambar 1 menunjukkan peta tektonik dari Cekungan Sumatera Selatan. Stratigrafi Cekungan Sumatera Selatan ditunjukkan oleh Gambar 2. Formasi Talang Akar terdapat di Cekungan Sumatra Selatan, formasi ini terletak di atas Formasi Lahat dan di bawah Formasi Baturaja dengan kontak formasi selaras. Formasi Talang Akar terdiri dari batupasir yang berasal dari delta plain, serpih, lanau, batupasir kuarsa, dengan sisipan batulempung karbonan, batubara dan di beberapa tempat konglomerat. Endapan Talang Akar didominasi endapan dari Tinggian Palembang dan Tinggian Tiga Puluh yang berada di utara hingga timur cekungan yang ditunjukan Gambar 3 . Dan ketebalan dari Formasi Talang Akar bervariasi 1500-2000 feet (sekitar 460-610 m) (Pulunggono, 1992). 


\section{TEORI DASAR}

\subsection{Metode Seismik Inversi}

Pengertian secara lebih spesifik tentang seismik inversi dapat didefinisikan sebagai suatu teknik pembuatan model bawah permukaan dengan menggunakan data seismik sebagai input dan data sumur sebagai kontrol (Simm dan Bacon, 2014). Definisi tersebut menjelaskan bahwa metode inversi merupakan kebalikan dari pemodelan dengan metode ke depan (forward modelling) yang berhubungan dengan pembuatan seismogram sintetik berdasarkan model bumi. Pada penelitian ini akan dibahas inversi post-stack yang berhubungan dengan inversi amplitudo yang menggunakan jenis inversi berbasis model (model based)

\subsubsection{Inversi Seismik Model Based}

Pada metode ini langkah yang pertama dilakukan adalah membangun model geologi, kemudian model tersebut dibandingkan dengan data seismik, diperbaharui secara iteratif sehingga didapatkan kecocokan yang lebih baik dengan data seismik. Semakin banyak iterasinya maka koefisien korelasi antara seismik sintetik dan seismik riilnya akan semakin besar dan error semakin kecil. Keuntungan penggunaan metode inversi berbasiskan model adalah metode ini tidak menginversi langsung dari seismik melainkan menginversi model geologinya (Simm dan Bacon, 2014).

\subsection{Metode Petrofisika}

Analisis petrofisika merupakan analisis yang dilakukan pada lapangan ukur dengan data sumur sebagai data utamanya. Analisis ini dilakukan guna mengetahui besaran berasan fisis tertentu didalam suatu formasi dalam satuan besar atau litologi dalam satuan kecil. Lebih kecil lagi, analisis ini dapat menentukan nilai perkedalaman dengan interval kedalaman tertentu (Harsono, 1997).

\subsubsection{Analisis Kualitatif}

Analisis ini merupakan analisis secara langsung dengan menggunakan data sumur sebagai pembacaan utamanya. Analisis ini memanfaatkan data hasil penngukuran langsung dilapangan yang terdiri dari data log Gamma Ray (GR), Spontaneous Potential (SP) dan Caliper dalam penentuan zona permeabelnya. Serta dukungan data log NPHI dan $R H O B$ dalam identifikasi reservoar berikut $\log$ Resistivitas Deep (LLD / ILD) dalam identifikasi kandungan reservoir.

\subsubsection{Analisis Kuantitatif}

Analisis kuantitatif memanfaatkan data log hasil pengukuran dalam input perhitungannya. Dalam fase analisis ini, dilakukan perhitungan nilai volume shale $(V s h)$, Porositas total dan efektif, saturasi air $(S w)$ dan permeabilitas menggunakan Persamaan 1 hingga Persamaan 5. Hasil akhirnya adalah menerapkan metode pemenggalan data (lumping) menggunakan batasan nilai (cut-off).

$$
\begin{aligned}
& I G R=\frac{G R_{\text {log }}-G R_{\min }}{G R_{\max }-G R_{\min }} \\
& V s h=0.083\left(2^{3.7 x I G R}-1\right) \\
& \Phi D=\frac{\rho_{m a}-\rho_{b}}{\rho_{m a}-\rho_{f}} \\
& \Phi_{\text {tot }}=\frac{\Phi N+\phi D}{2} \\
& \Phi_{\text {eff }}=\sqrt{\frac{\phi D c^{2}+\phi N c^{2}}{2}} \\
& \Phi D c=\Phi D-(\Phi D \operatorname{sh} x V s h) \\
& \Phi N c=\Phi N-(\Phi N \operatorname{sh} x V s h)
\end{aligned}
$$




$$
\begin{aligned}
& \frac{1}{\sqrt{R_{\mathrm{L}}}}=\left[\frac{W_{s h}\left(1-\frac{V s h}{2}\right)}{\sqrt{R_{s h}}}+\frac{\phi_{s}{ }^{m / 2} / 2}{\sqrt{a \cdot R_{w g}}}\right] \cdot S_{W W}^{n / 2}(8) \\
& k=a \cdot \frac{\phi^{b}}{S \mathbb{V}^{c}} \\
& \begin{aligned}
I G R & =\text { Indeks Gamma Ray } \\
V S h & =\text { Volume Shale } \\
G R & =\text { Nilai gamma ray pada } \\
& \text { kurva } \\
\phi D & =\text { Porositas Densitas }
\end{aligned} \\
& \rho_{m a}=\text { Dansitas matriks batuan } \\
& \rho_{b} \quad=\text { Densitas matriks batuan } \\
& \text { dari log (gr/cc) } \\
& \rho_{f} \quad=\text { Densitas Fluida } \\
& \phi_{\text {tot }}=\text { Porositas total } \\
& \phi N=\text { Porositas Neutron / NPHI } \\
& \phi D c=\text { Koreksi porositas densitas } \\
& \phi N c=\text { Koreksi porositas neutron } \\
& \phi D s h=\text { Porositas densitas shale } \\
& \phi D s h=\text { Porositas neutron shale } \\
& S w=\text { Saturasi Air (\%) } \\
& R t \quad=\text { Resistivitas Formasi } \\
& R w=\text { Resistivitas air formasi } \\
& R s h=\text { Resistivitas shale } \\
& V s h=\text { Volume shale }(\%) \\
& \phi e=\text { porositas efektif }(\%) \\
& a=\text { faktor turtuositi } \\
& m \text { = faktor sementasi } \\
& n \quad=\text { eksponen saturasi } \\
& k=\text { permeabilitas } \\
& a \quad=\text { konstanta Schlumberger } \\
& =10000 \\
& b \quad=\text { konstanta Schlumberger } \\
& =4.5 \\
& \text { c } \quad=\text { konstanta Schlumberger } \\
& =2
\end{aligned}
$$

\subsection{Metode Perhitungan Cadangan Hidrokarbon}

Perhitungan cadangan hidrokarbon menggunakan prinsip map algebra, dimana tiap titik dengan spasi $\mathrm{x}$ dan $\mathrm{y}$ tertentu memiliki nilai cadangannya sendiri. hasil operasi pada peta perlu dijumlahkan untuk mendapatkan nilai cadangan total, karena persamaan hanya mengoperasikan bilangan pada titik yang sama memanfaatkan Persamaan 10 untuk minyak dan Persamaan 11 untuk gas (Triwibowo, 2010).

$$
\begin{aligned}
& \text { OOIP }=\frac{A x h x \phi x\left(1-S_{W W}\right)}{\text { Boi }} \times 7758 \\
& O G I P=\frac{A x h x \phi x\left(1-S_{w w}\right)}{B g i} \times 43560
\end{aligned}
$$

Dimana,

$$
\begin{array}{ll}
\text { OOIP } & \begin{array}{c}
\text { Original Oil in Place } \\
\text { Stock Tank Barrels })
\end{array} \\
\text { OGIP } & =\text { Original Gas in Place } \\
7758 & =\text { Faktor Konversi dari acre/ft ke } \\
\text { barrel. } & =\text { Faktor Konversi dari acre/ft } \\
43560 \quad & \text { ke MMSCF. } \\
& =\text { Porositas }(\%) \\
\text { S } & \text { Saturasi air }(\%) \\
\text { Sw } & \text { Oil formation volume } \\
\text { Boi } & \text { factor (STB/bbls) } \\
\text { Bgi } & \text { Gas formation volume } \\
& \text { factor (Vidhotomo dkk., } \\
& \text { 2011). }
\end{array}
$$

\subsection{Operasi Map Algerbra}

Map algebra merupakan proses aritmarik sederhana yang dilakukan pada satu atau lebih peta untuk mendapatkan keluaran berupa peta baru (Berry, 2004). Pada operasi ini, dilakukan penyebaran properti reservoir menggunakan guide hasil $A I$ dengan memanfaatkan kontrol dari beberapa persamaan gradien hasil pengolahan. Output penyeraban adalah peta isopach, peta saturasi air dan peta porositas efektif secara netpay.

\section{HASIL DAN PEMBAHASAN}

\subsection{Pengolahan dan Analisis Data Seismik}

Data seismik yang digunakan merupakan data Post Stack Time Migration (PoSTM) dengan 6 data sumur yang yakni 228, 257, 260, 290, 291 dan 293. Hasil analisis menunjukan terdapat 
dua lapisan prospek pada area penelitian yakni S dan W3 ditunjukkan Gambar 4 sebagai sampel gambar. Selanjutnya dilakukan analisis crossplot sebagai uji sensitivitas sumur antara $\log P$-Impedance dan Gamma Ray serta Log P-Impedance dan $R H O B$. Diperoleh hasil bahwa data sumur hanya dapat memisahkan zona batupasir poros dan non-poros tanpa dapat memisahkan litologi. Hal ini dikarenakan terjadi overlap data ditunjukan oleh Gambar 5 sebagai sampel gambar. Tahap ini juga menentukan batasan cut-off densitas yang bernilai $2.53 \mathrm{gr} / \mathrm{cc}$ dan $A I$ (P-Impedance) dengan nilai 9315 $\mathrm{m} / \mathrm{s} * \mathrm{gr} / \mathrm{cc}$.

Selanjutnya dilakukan proses well seismic tie menggunakan sintetik seismogram hasil konvolusi wavelet ekstraksi dan koefisien refleksi. Proses ini juga memanfaatkan $\log D T$ sebagai kontrol pengikatan. Hasil menunjukan korelasi rata-rata 0.77 dengan time shift $0 \mathrm{~ms}$ yang disimpulkan proses berhasil. Setelah dilakukan fase ini dilakukan picking horizon dan fault lalu didapatkan time structure map. Peta struktur waktu kemudian dikonversi menggunakan velocity modeling process dengan velocity single well sebagai kontrolnya hingga didapatkan peta struktur kedalaman lapisan S dan W3 seperti pada Gambar 6 dan Gambar 7. Hasil menunjukan terdapat struktur antiklin yang merupakan bagian dari antiklinorium limau berarah Barat Laut-Tenggara. Pada peta telah dilakukan input batas oil water contact (OWC), artinya, area dibawah $O W C$ yang tidak berkontur dianggap tidak produktif karena tersaturasi tinggi. Patahan yang ada berorientasi Timur Laut-Barat Daya dan diidentifikasikan sebagai patahan turun yang dapat bertindak sebagai jalur migrasi hidrokarbon.

Hasil akhir dari proses pengolahan data seismik adalah hasil inversi $A I$ yang dilakukan. Porses inversi menggunakan proses inversi akustik impedance dengan metode model based. Berdasarkan hasil interpretasi crossplot sebelumnya, diketahui bahwasannya nilai cut-off $A I$ untuk area penelitian adalah pada nilai $9315 \mathrm{~m} / \mathrm{s}^{*} \mathrm{gr} / \mathrm{cc}$. Sehingga, hasil yang didapatkan adalah sebaran zona prospek dibawah nilai cut-off yang diinterpretasikan sebagai batupasir poros dengan rentang AI pada nilai 7400 - 9315 $\mathrm{m} / \mathrm{s}^{*} \mathrm{gr} / \mathrm{cc}$ untuk kedua lapisan. Pola zona poros menunjukan pola pengendapan sedimen area penelitian datang dari arah utara hingga timur dan diinterpretasi berada pada sistem pengendapan flufial hingga shallow marine. Hal ini ditunjukan oleh Gambar 8 dan Gambar 9.

Dilakukan penurunan parameter $A I$ menjadi parameter densitas pada area penelitian sehingga didapatkan pola sebaran densitas area penelitian lapisan $\mathrm{S}$ dan lapisan W3 yang selanjutnya digunakan sebagai input utama dalam penyebaran properti reservoir. Adapun pola sebaran densitas memiliki keseragaman pola terhadap pola sebaran AI.

\subsection{Pengolahan dan Analisis Petrofisika}

Berdasarkan data sumur yang ada, dilakukan interpretasi baik secara kualitatif dan kuantitatif. Gambar $\mathbf{1 0}$ hingga Gambar 15 menunjukan hasil interpretasi kualitatif keenam data sumur yang menunjukan hasil bahwasannya lapisan $\mathrm{S}$ produktif ditemukan pada sumur 260, 290 dan 291 sedangkan lapisan W3 Produktif berada pada sumur 228 dan 257. Sumur 293 diidentifikasi tidak prospek pada kedua lapisan. Hasil interpretasi juga menunjukan baik lapisan $\mathrm{S}$ dan $\mathrm{W} 3$ hanya prospek minyak sehingga, area penelitian dinyatakan tidak prospek gas.

Selanjutnya dilakukan interpretasi clay parameter guna menentukan batas sand baseline (GR Min) dan shale baseline (GR Max) untuk diinput pada interpretasi volume shale. Proses ini menggunakan sistem crossplot antara NPHI, RHOB dan $G R$ sebagai indikator warna serta $N P H I$, $G R$ dan $R H O B$ sebagai indikator warna. 
Gambar 16 dan Gambar 17 menunjukan interpretasi clay parameter dan didapatkan hasil nilai sand baseline berada pada 35 API dan shale baseline berada pada 170 API. Gambar 18 menunjukan proses perhitungan volume shale salah satu sumur.

Identifikasi nilai resistivitas air formasi $(R w)$ dan resistivitas lumpur pemboran $(R m f)$ juga seharusnya dilakukan. Namun, pada penelitian ini, nilai $R w$ yang digunakan merupakan nilai hasil uji laboratorium dan nilai $R m f$ didapatkan dari well head yang merupakan hasil pengukuran langsung pada uji mud filtrate. Sehingga, tidak dilakukan interpretasi nilai $R w$ dan $R m f$.

Setelah didapatkan beberapa parameter diatas dan dilakukan perhitungan secara kuantitaif menggunakan Persamaan 1 dan Persamaan 2 untuk Vshale, Persamaan 3 hingga Persamaan 7 untuk PHIT dan PHIE, Persamaan 8 untuk $S w$ dan Persamaan 9 untuk permeabilitas, didapatkan hasil bahwasannya pada zona prospek baik lapisan $\mathrm{S}$ dan $\mathrm{W} 3$ nilai volume shale berada pada rentang $6,1 \%$ hingga $15,7 \%$ yang dinyatakan lapisan reservoir masih digolongkan bersih. Nilai porositas efektif (PHIE) berada pada nilai 16,6\% hingga 20,6\%; Nilai Saturasi Air pada rentang $29,1 \%$ hingga $47,6 \%$; dan nilai permeabilitas pada rentang $41 \mathrm{mD}$ hingga $310 \mathrm{mD}$. Hasil interpretasi keseluruhan diketahui lapisan target merupakan lapisan produktif dengan tingkat saturasi air yang rendah dengan permeabilitas baik hingga sangat baik yang berkorelasi linear terhadap porositas efektif (PHIE).

Fase penentuan nilai cut-off dilakukan setelah proses diatas dengan metode crossplot. Cut-off porositas efektif (PHIE) didapatkan dengan meng-crossplot nilai PHIE terhadap permeabilitas (K). Setelah dilakukan penarikan garis poligon pada sebaran data di area reservoir, dibaca garis poligon saat nilai $\mathrm{K}$ adalah $1 \mathrm{mD}$ yang merupakan $\mathrm{K}$ minimum formasi dalam mengalirkan minyak. Nilai terbaca rata-rata pada keseluruhan sumur adalah $10,3 \%$ yang selanjutnya dianggap sebagai nilai cut-off porositas efektif. Cut-off volume shale didapatkan dengan crossplot antara PHIE terhadap Volume shale (VSh atau $V C l$ ) titik data tertinggi pada batas nilai cut-off PHIE (10,3\%) merupakan data dengan volume shale tertinggi yang masuk dalam kategori produktif minimum berdasarkan cut-off PHIE. Sehingga, nilai $\mathrm{VCl}$ terbaca pada data tersebut dianggap sebagai cut-off Volume Shale atau cut-off pengotor yakni pada nilai rata-rata tiap sumur adalah 31,9\%. Sedangkan cut-off $S w$ didapatkan dari hasil uji lab menggunakan crossplot $S w$ terhadap $W c$ (Water Cut) yang didapatkan nilai cut-off $63 \%$ untuk lapisan W3 dan 68\% untuk lapisan S. Gambar 19 menunjukan crossplot pada identifikasi cut-off PHIE dan crossplot VSh.

Nilai crossplot diatas kemudian diaplikasikan dalam proses lumping data (pemenggalan data) yang dianggap movable hidrocarbon atau hidrokarbon yang diinterpretasikan dapat diproduksi dalam suatu reservoir. Hasil lumping menunjukan lapisan W3 lebih tebal pada nilai $6,4 \mathrm{~m}$ hingga $11,4 \mathrm{~m}$ dibanding lapisan $\mathrm{S}$ pada nilai $2,8 \mathrm{~m}$ hingga $4,2 \mathrm{~m}$. Perbandingan ketebalan gross (reservoir) terhadap nilai ketebalan net (pay) atau $\mathrm{G} / \mathrm{N}$ rata-rata lapisan $\mathrm{S}$ adalah $7.6 \mathrm{~m}$ dan lapisan W3 adalah $2.0 \mathrm{~m}$. Nilai $\mathrm{G} / \mathrm{N}$ ini diaplikasikan pada peta ketebalan (isopach) gross untuk mendapatkan peta ketebalan pay.

\subsection{Map Analysis}

Proses ini bertujuan untuk memperoleh peta sebaran properti reservoir yang akan menjadi input dalam perhitngan cadangan. Peta pertama yakni peta isopach pay (ketebalan bersih) yang diperoleh dengan membagi peta isopach gross (ketebalan kotor) reservoir hasil picking top dan bottom reservoir dengan 
nilai $\mathrm{G} / \mathrm{N}$ tiap lapisan. Hasilnya ditunjukkan pada Gambar 20. Selanjutnya dilakukan penyebaran properti porositas efektif dengan memanfaatkan gradien persamaan hasil crossplot antara $R H O B$ terhadap PHIE pada semua data sumur yang dijadikan satu hingga diperoleh gradien $\quad \mathrm{y}=-0.503 \mathrm{x}+1.3501 \quad$ yang sebelumnya dikorelasikan dengan nilai korelasi -0.91 (terkorelasi sangat tinggi). Pada gradien persamaan, fungsi $\mathrm{x}$ yang menajdi input adalah peta sebaran densitas $(R H O B)$ hasil pengurunan atribut pada proses inversi $A I$ dimana y merupakan peta sebaran porositas efektif. Hasilnya ditunjukkan pada Gambar 21. Terakhir, dilakukan penyebaran properti saturasi air $(S w)$ dimana persamaan buckles menjadi kontrol utamanya. Persamaan ini memanfaatkan nilai konstanta batuan reservoir. Dimana, pada lapangan Bisma, batuan reservoir adalah sandstone dengan nilai konstanta hasil perhitungan adalah 0,067. Persamaan buckles menunjukan hubungan porositas terhadap saturasi air $(S w)$ dengan persamaan $S w=$ konstanta / porositas. Pada kasus ini, porositas yang menjadi input adalah peta sebaran PHIE hasil sebelumnya dan konstanta yang diinput adalah konstanta tunggal 0,067. Hasil peta sebaran $S w$ ditunjukkan pada Gambar 22.

Sebelum dilakukan perhitungan cadangan hidrokarbon, dilakukan pemotongan (cutting) peta terlebih dahulu. Hal ini bertujuan untuk menghilangkan data lapisan yang tidak produktif. Untuk dapat dilakukan fase perhitungan secara map algebra, jumlah cell tiap peta haruslah sama yang artinya luas hasil potongan pada peta harus sama. Batas yang dianggap sebagai zona produktif adalah batas yang ditunjukan pada peta sebaran PHIE yang diindikasikan paling representatif untuk memisahkan area poros dan non-poros pada batas 10,3\%. Hasil potongan peta ditunjukan oleh Gambar 23 untuk lapisan S sebagai sampel.

\subsection{Perhitungan Cadangan Hidrokarbon}

Menggunakan input peta yang telah dilakukan cutting sebelumnya, dilakukan proses perhitungan cadangan hidrokarbon menggunakan Persamaan 10 dikarenakan area penelitian hanya prospek minyak. Peta isopach mengambil porsi Axh pada persamaan sedangkan peta PHIE mengambil porsi $\phi$ dan peta Saturasi air mengambil porsi $S w$. Nilai Boi didapatkan dari data uji laboratorium yakni pada nilai 1,274 pada lapangan Bisma. Setelah dilakukan proses aritmatik pada peta, secara langsung didapatkan peta sebaran akumulasi minyak area penelitian pada Gambar 24. Dari gambar tersebut, diketahui akumulasi minyak terbanyak tidak terkonsentrasi pada area antiklin sehingga diidentifikasikan bahwasannya baik lapisna S maupun W3 memiliku tipe jebakan stratigrafi bukan jebakan struktur.

Hasil akumulasi cell pada peta menunjukan nilai cadangan lapisan pada penelitian. Lapisan $\mathrm{S}$ teridentifikasi mengakumulasi sebesar 21,1 juta barrel oil dan lapisan W3 mengakumulasi 50,2 juta barrel oil. Dengan akumulasi keseluruhan lapangan Bisma memiliki cadangan minyak sebesar 71,3 juta barrel pada lapisan S dan W3.

\section{KESIMPULAN}

Adapun kesimpulan dari penelitian ini adalah sebagai berikut,

1. Reservoir batupasir memiliki nilai $A I$ pada rentang $7400-9315 \mathrm{~m} / \mathrm{s}^{*} \mathrm{gr} / \mathrm{cc}$ dengan metode inversi seismik impedansi akustik dan hasil inversi berdasarkan analisis crossplot hanya dapat memisahkan antara lapisan poros dan non-poros.

2. Lapisan $\mathrm{S}$ dan W3 sebagai zona terget teridentifikasi prospek minyak berdasarkan hasil interpretasi data petrofisika dengan hasil lumping menunjukan ketebalan pada rentang 
$6.4 \mathrm{~m}$ hingga $11.4 \mathrm{~m}$ untuk lapisan W3 dan $2.8 \mathrm{~m}$ hingga $4.2 \mathrm{~m}$ untuk lapisan $\mathrm{S}$.

3. Batas body sandstone menggunakan batas yang ditunjukan oleh peta sebaran porositas. Batas body sandstone peta porositas digunakan sebagai cut-off untuk memeroleh peta netpay tiap parameter.

4. Hasil perhitungan cadangan minyak untuk lapisan S adalah 21.1 juta barrel dan lapisan W3 sebesar 50.2 juta barrel dengan total 71.3 juta barrel untuk lapangan Bisma.

\section{DAFTAR PUSTAKA}

Berry, J.K. 2004. Bridging GIS and Map Analysis: Identifying and Utilizing Spatial Relationships. ASPRS Annual Conference, p. 1 - 9.

Doust, H. dan Noble, R.A. 2008. Petroleum Systems of Indonesia. Marine and Petroleum Geology Elsevier - Marine and Petroleum Geology, 25, p. 103 - 129.

Ginger, D. dan Fielding, K. 2005. The Petroleum Systems and Future Potential of the South Sumatera Basin. Proceedings Indonesian Petroleum Association 2005, IPA05-G-039, p. 67 - 89.

Harsono, A. 1997. Evaluasi Formasi dan Aplikasi Log: Edisi Revisi-8. Schlumberger Oil Services: Indonesia

Pulunggono, A., Haryo S. dan Kosuma, C.G. 1992. Proceedings Indonesian Petroleum Association: PreTertiary and Tertiary Fault Systems as a Framework of the South Sumatera Basin; a Study of SARMaps. Proceedings Indonesian Petroleum Association 1992, IPA92-11.37, p. 339 - 360.

Simm, R. dan Bacon, M. 2014. Seismic Amplitude: An Interpreter's
Handbook. Cambridge University Press: UK.

Sukmono, S., 2000. Seismik Inversi Untuk Karakterisasi Reservoar. Bandung: Departemen teknik Geofisika Institut Teknologi Bandung.

Triwibowo, B. 2010. Cut-off Porositas, Volume Shale, dan Saturasi Air untuk Perhitungan Netpay Sumur O Lapangan C Cekungan Sumatera Selatan. Jurnal Ilmiah MTG, 3 (2). 


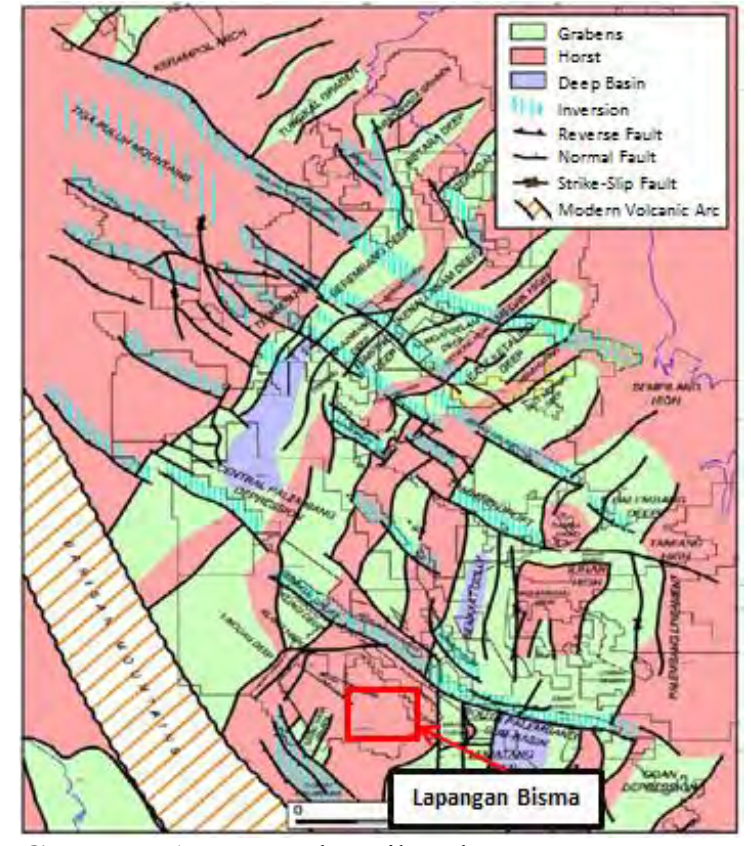

Gambar 1. Peta tektonik cekungan sumatera selatan (Ginger dan Fielding, 2005)

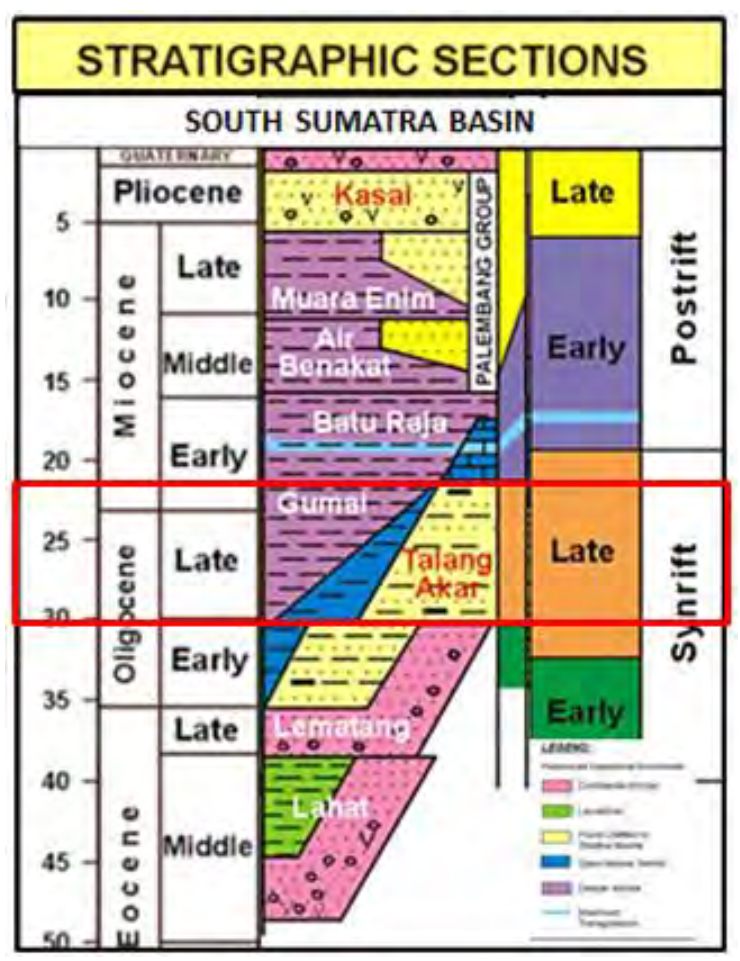

Gambar 2. Stratigrafi cekungan sumatera selatan (Doust dan Noble, 2008)

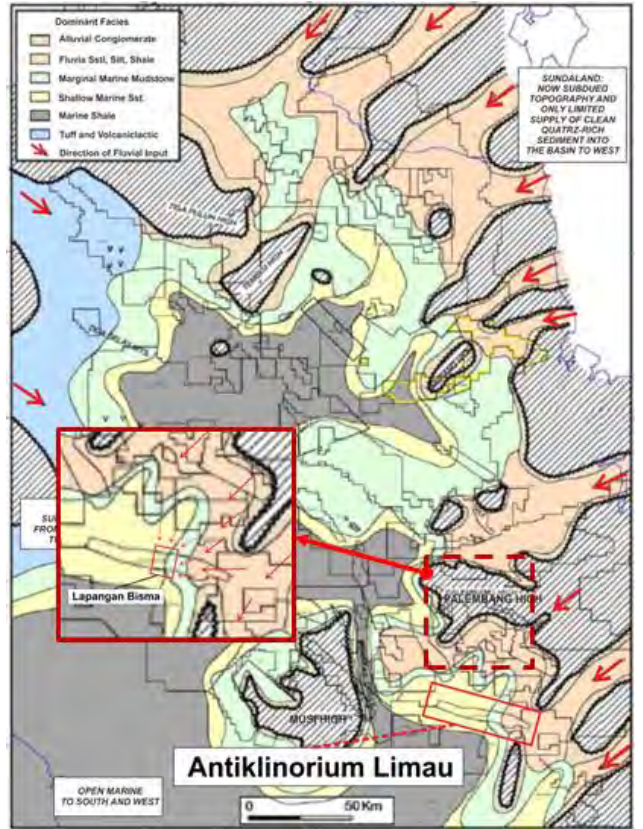

Gambar 3. Lingkungan pengendapan TRM cekungan sumatera selatan (Ginger dan Fielding, 2005).

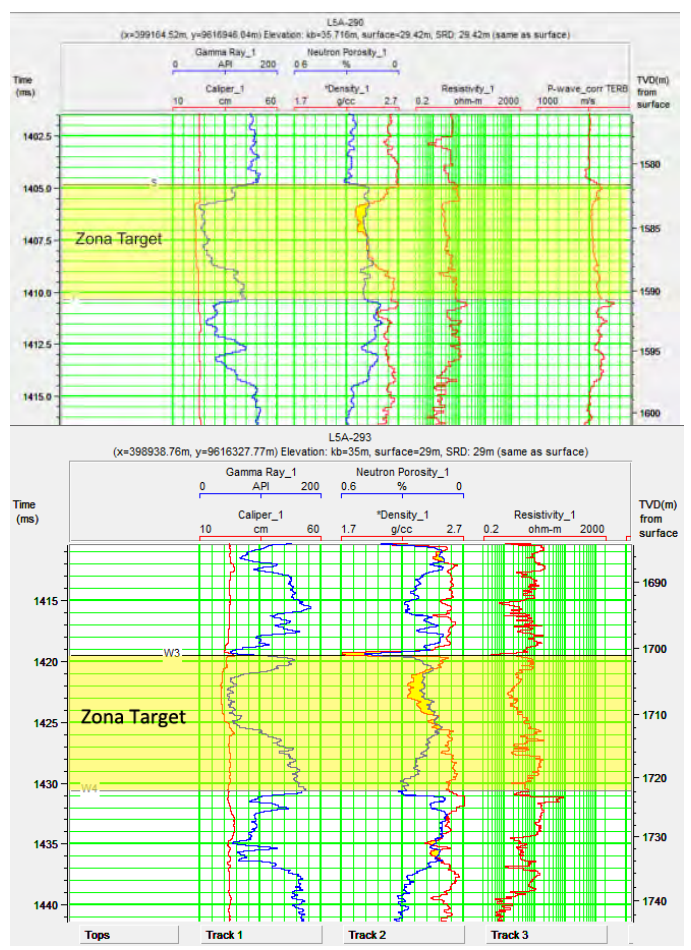

Gambar 4. Identifikasi zona terget S dan W3 


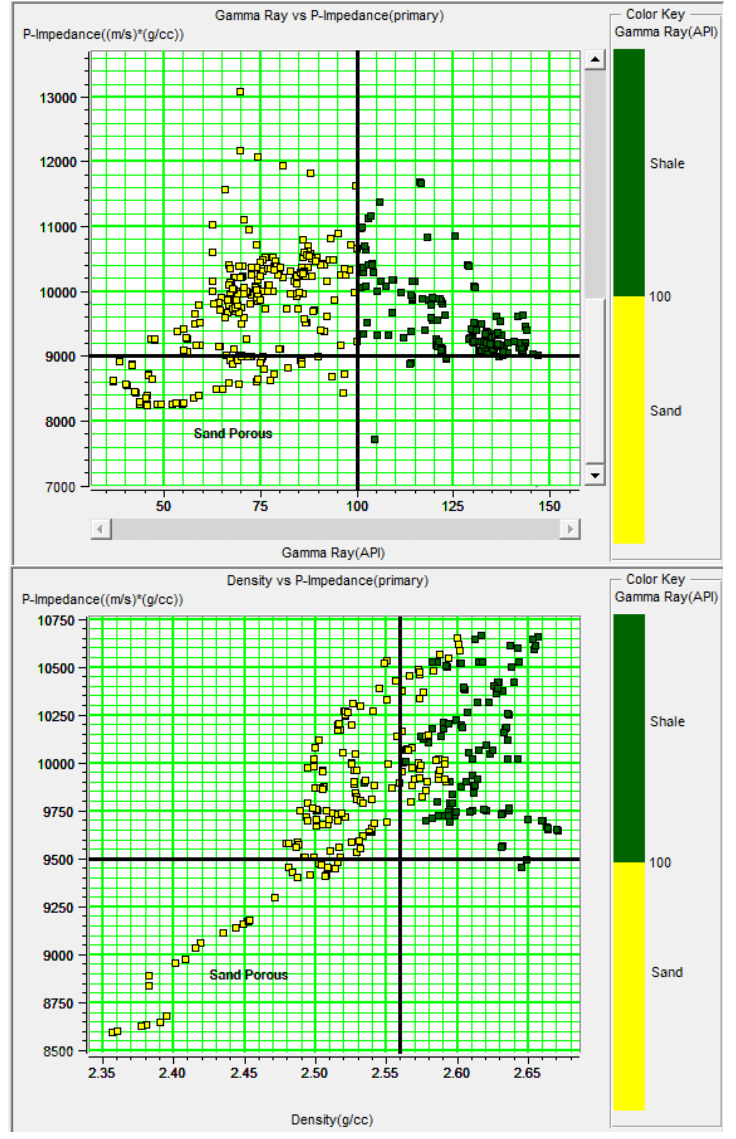

Gambar 5. Analisis crossplot PI-GR dan PI$R H O B$

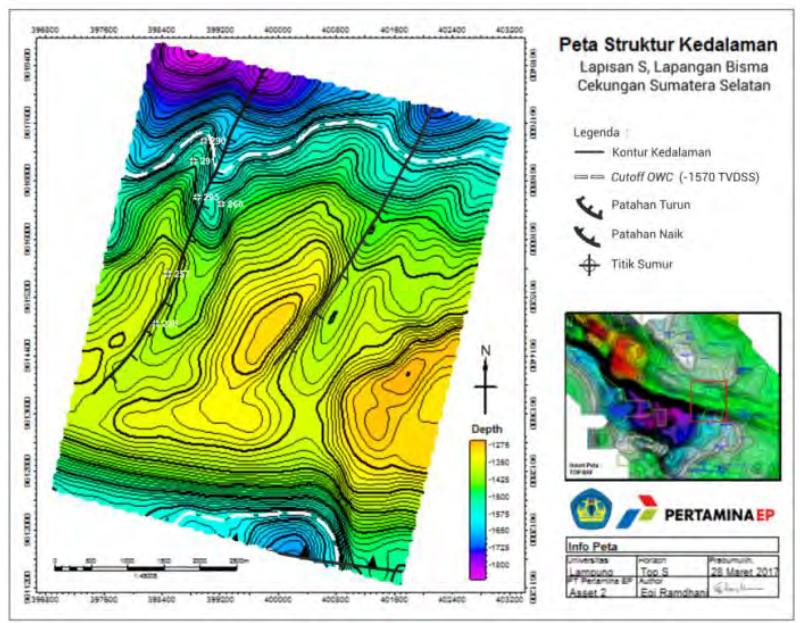

Gambar 6. Peta struktur kedalaman lapisan S

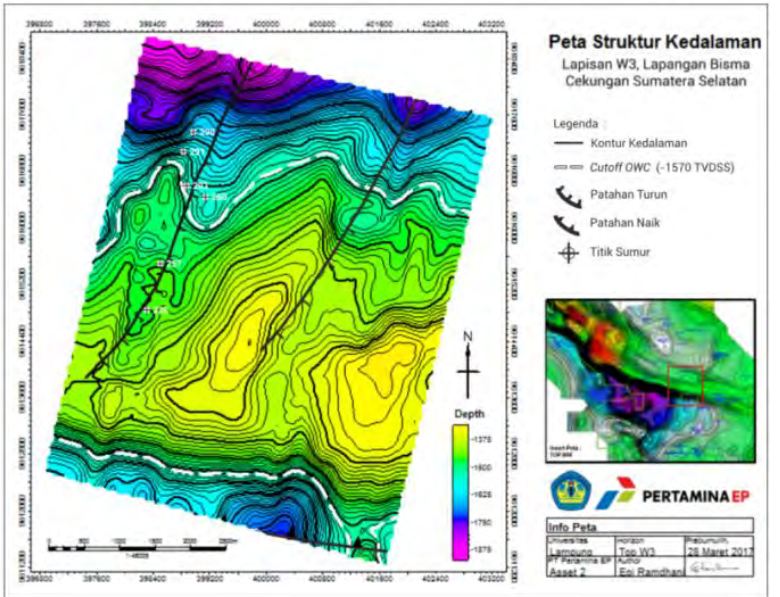

Gambar 7. Peta struktur kedalaman lapisan W3

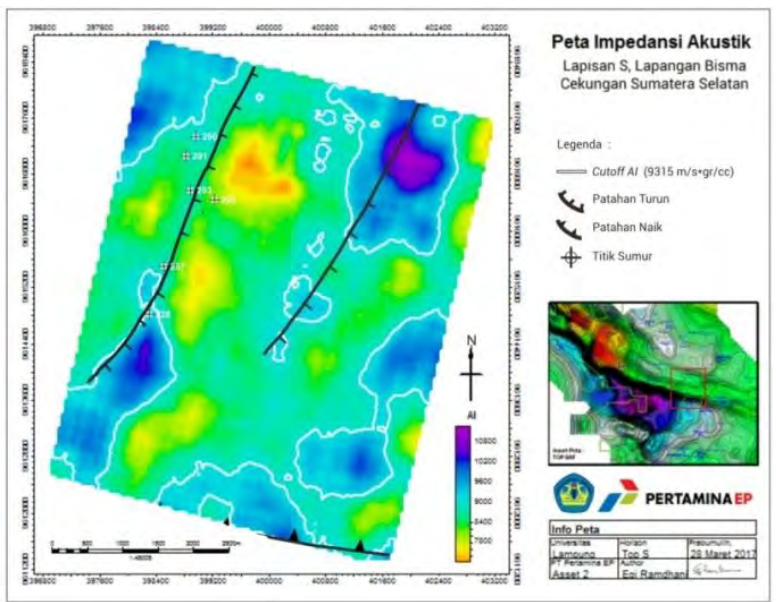

Gambar 8. Distribusi $A I$ Lapisan S, indikator distribusi sandstone.

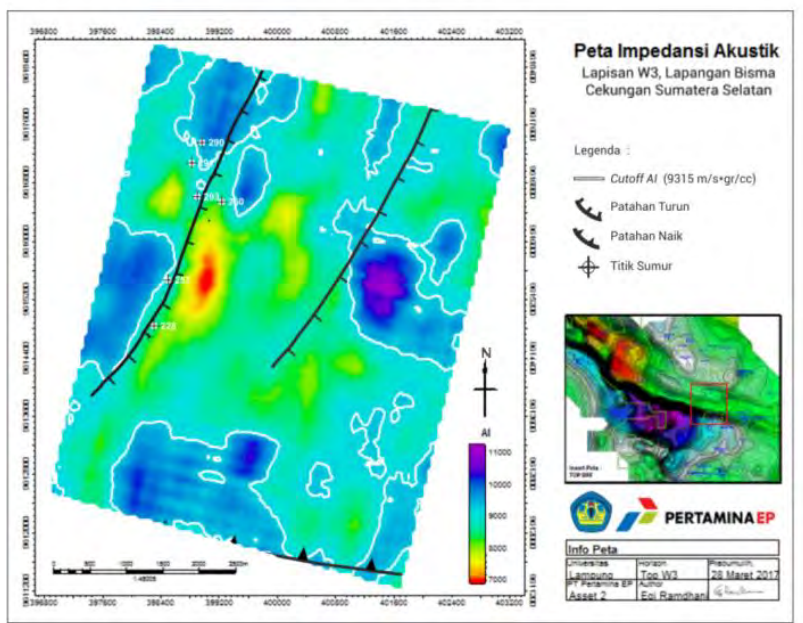

Gambar 9. Distribusi $A I$ Lapisan W3, indikator distribusi sandstone. 


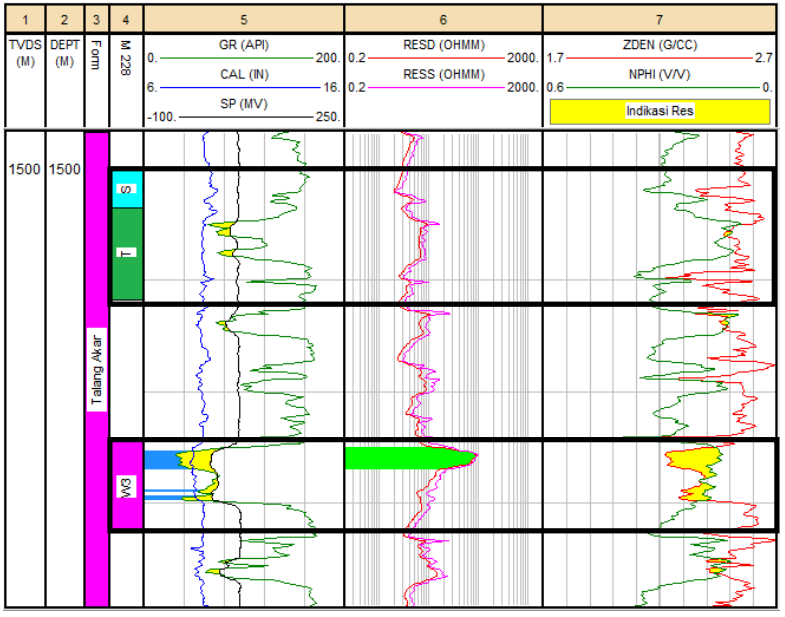

Gambar 10. Interpretasi kualitatif zona target sumur 228 pada tampilan triple combo.

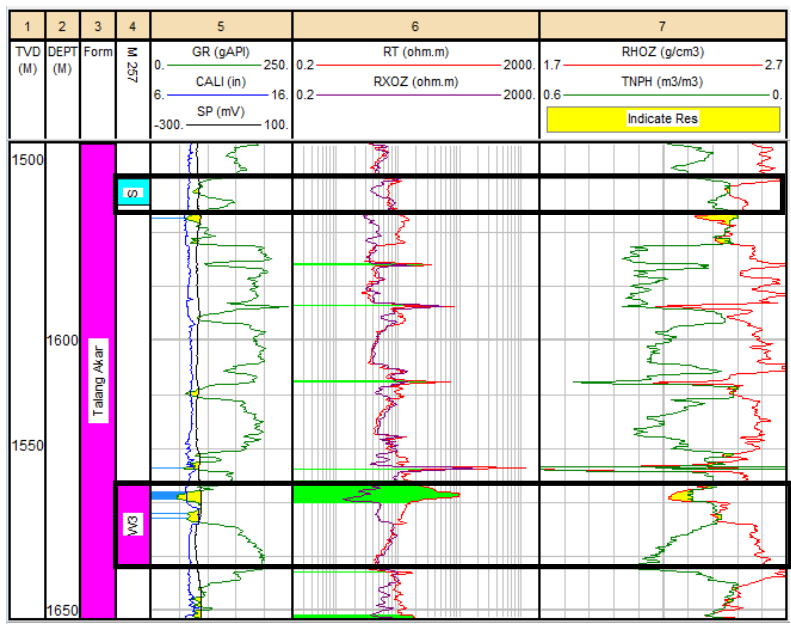

Gambar 11. Interpretasi kualitatif zona target sumur 257 pada tampilan triple combo.

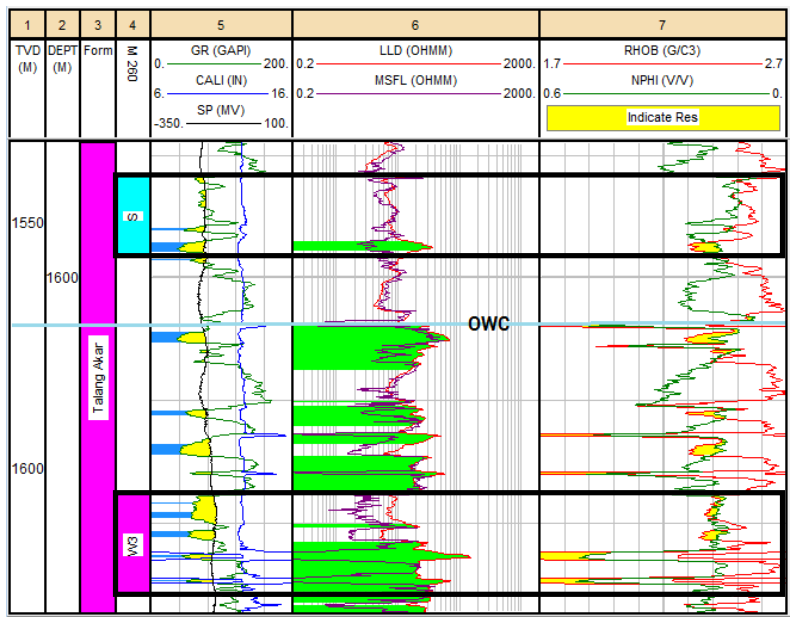

Gambar 12. Interpretasi kualitatif zona target sumur 260 pada tampilan triple combo.

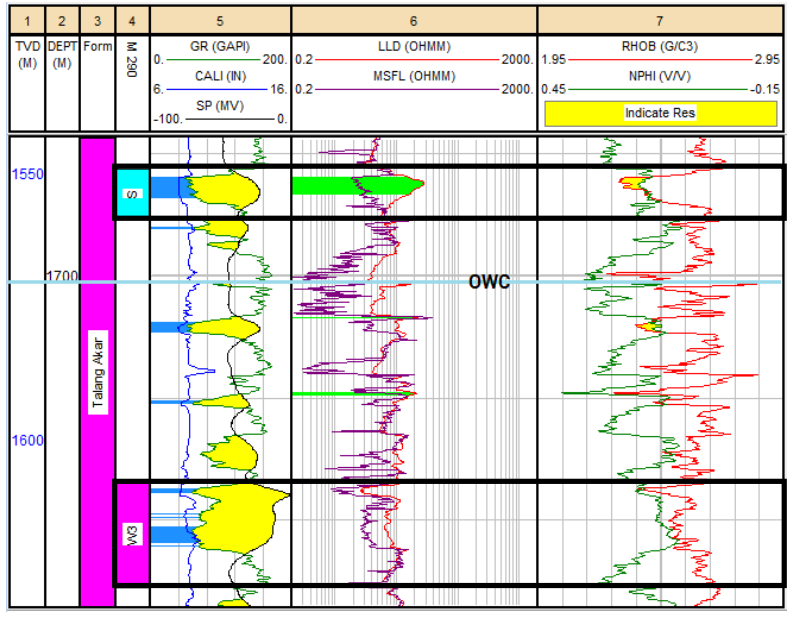

Gambar 13. Interpretasi kualitatif zona target sumur 290 pada tampilan triple combo.

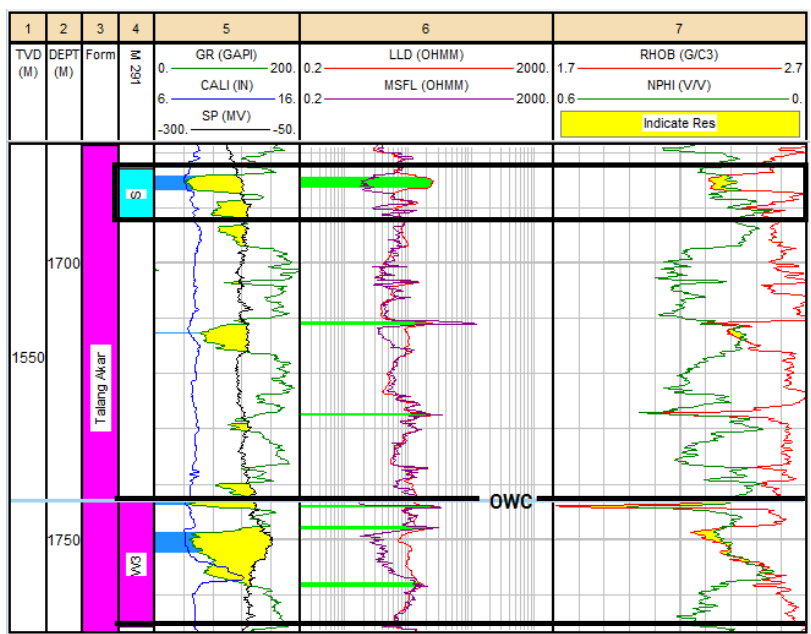

Gambar 14. Interpretasi kualitatif zona target sumur 291 pada tampilan triple combo.

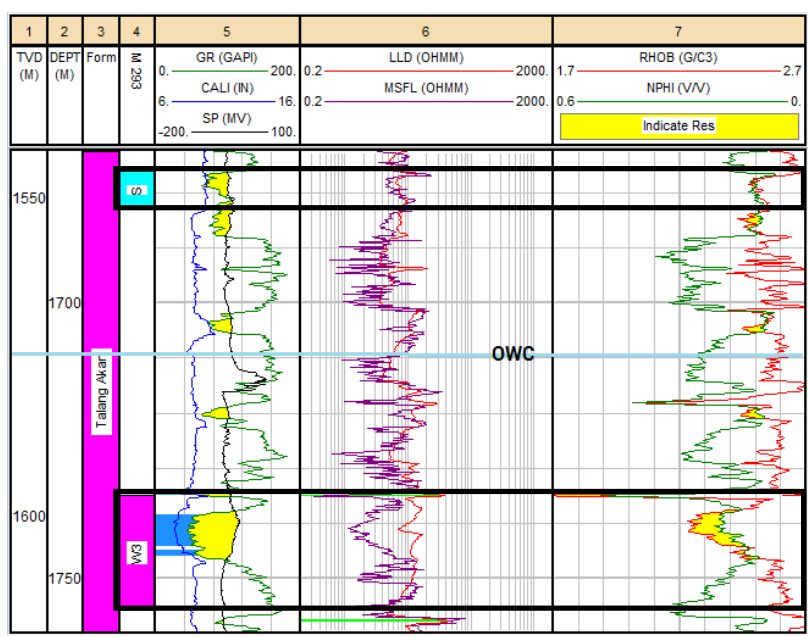

Gambar 15. Interpretasi kualitatif zona target sumur 293 pada tampilan triple combo. 

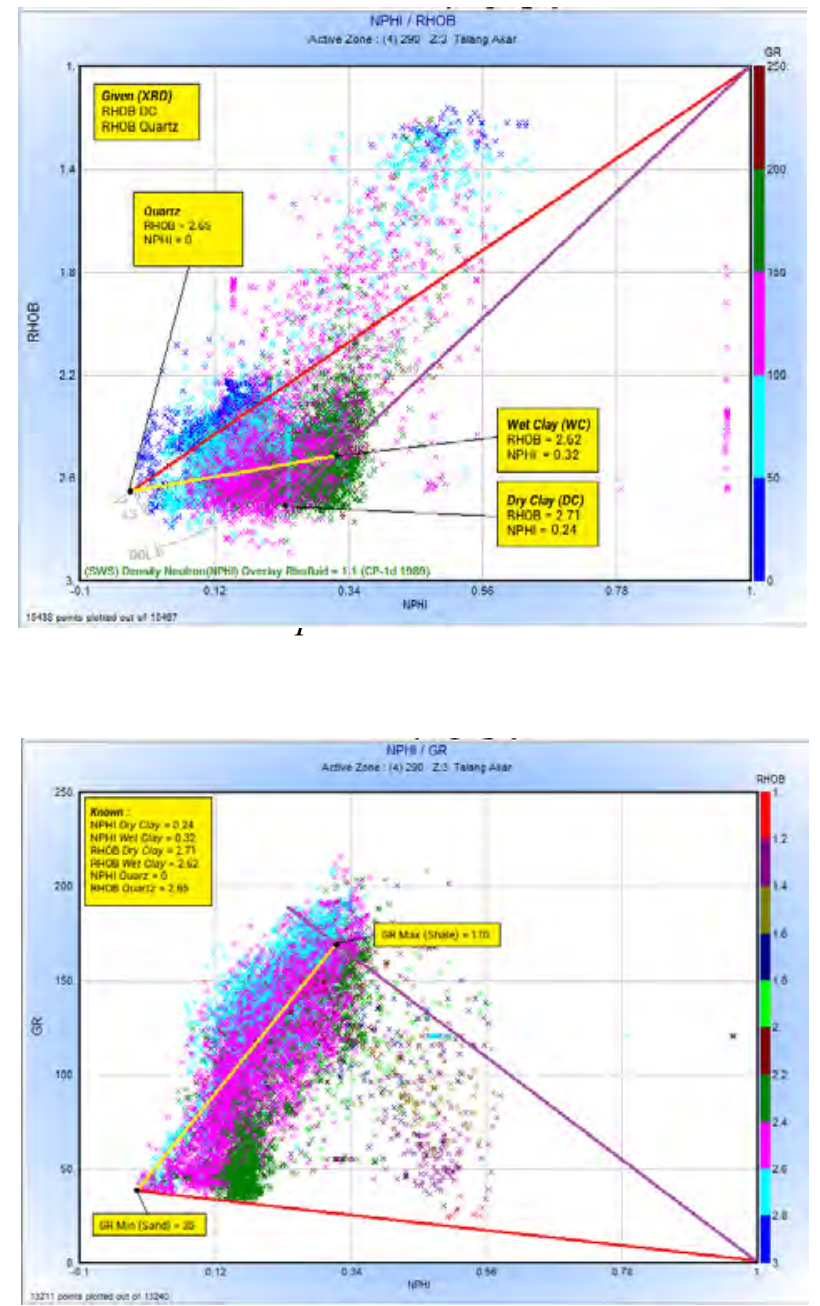

Gambar 17. Interpretasi clay parameter crossplot NPHI/GR

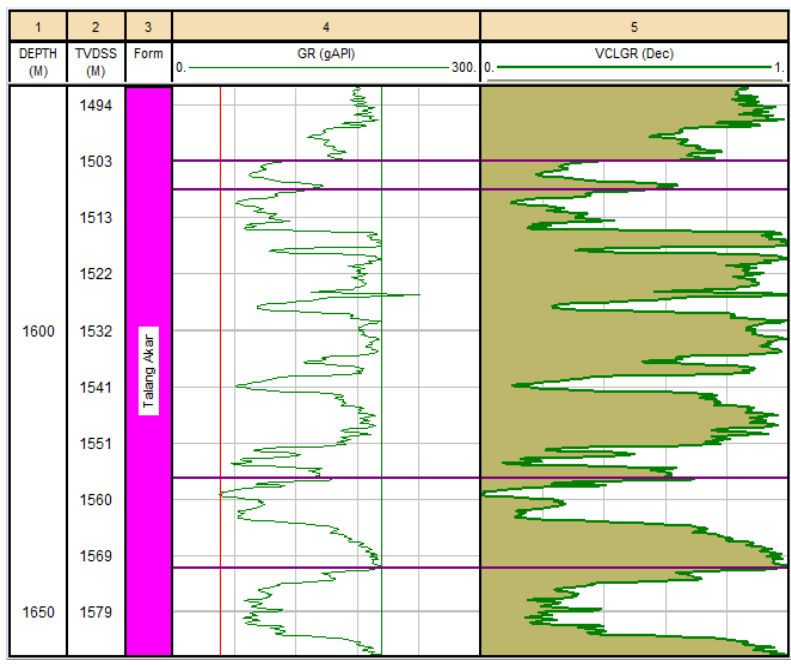

Gambar 18. Vsh interpretation
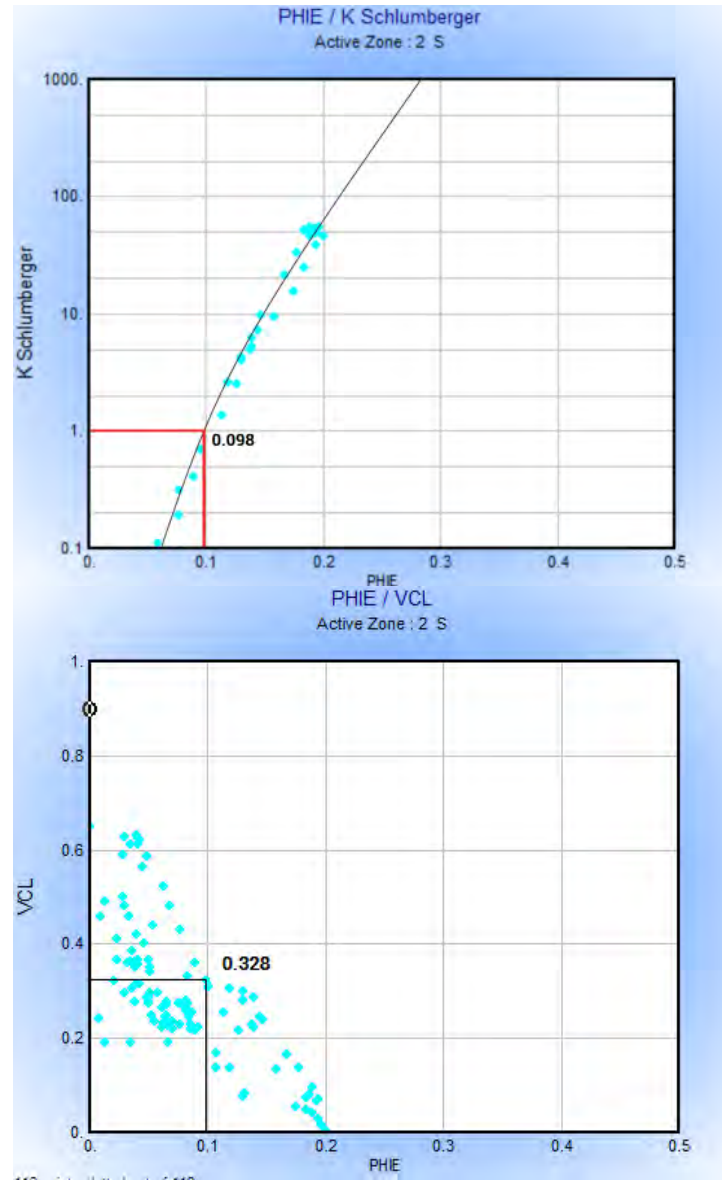

Gambar 19. PHIE cut-off (crossplot PHIE/K) dan VSh cut-off (crossplot PHIE/Vsh) 


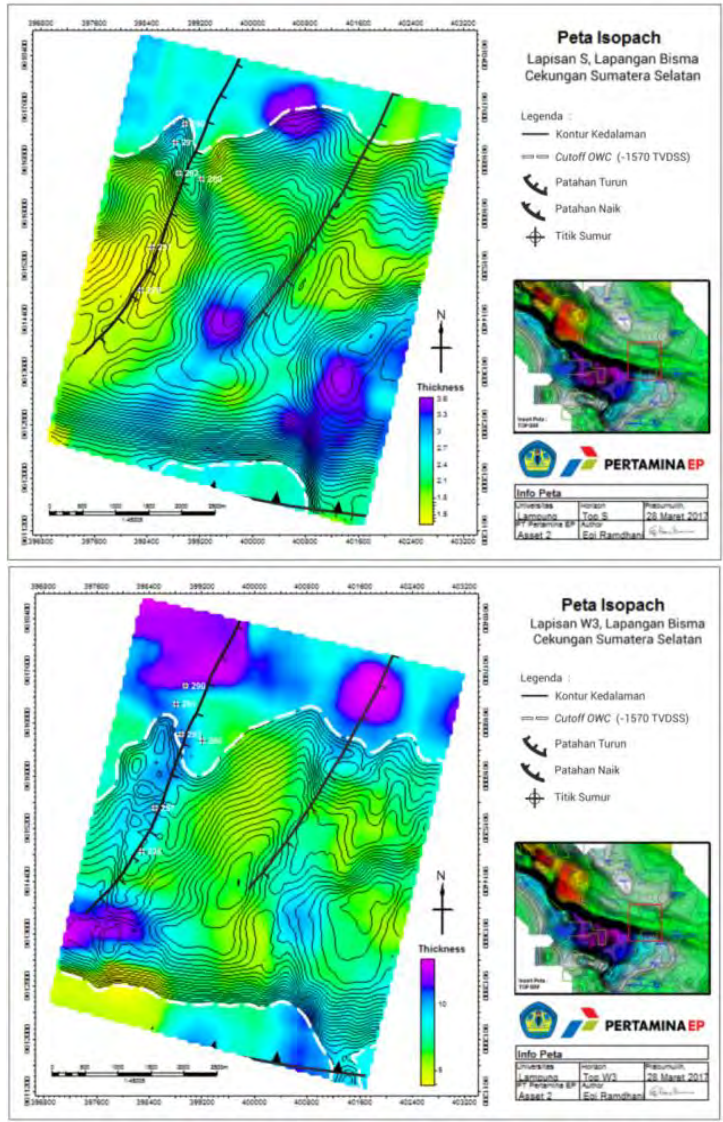

Gambar 20. Peta isopach lapisan S dan W3

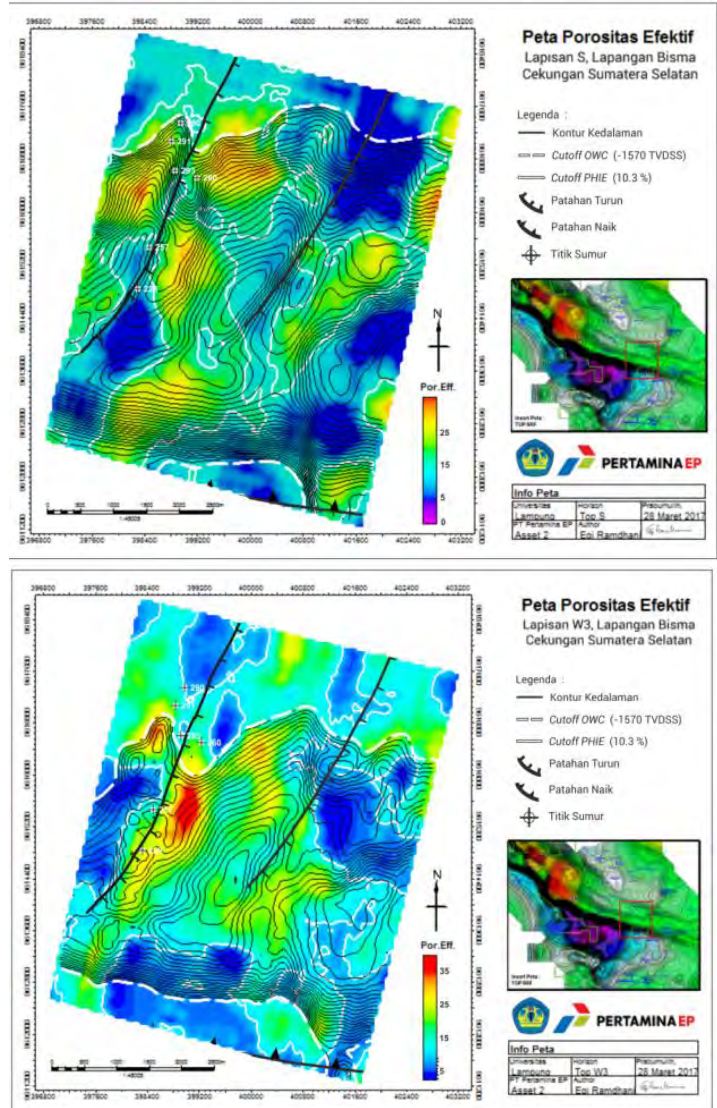

Gambar 21. Peta sebaran PHIE lap. S dan W3
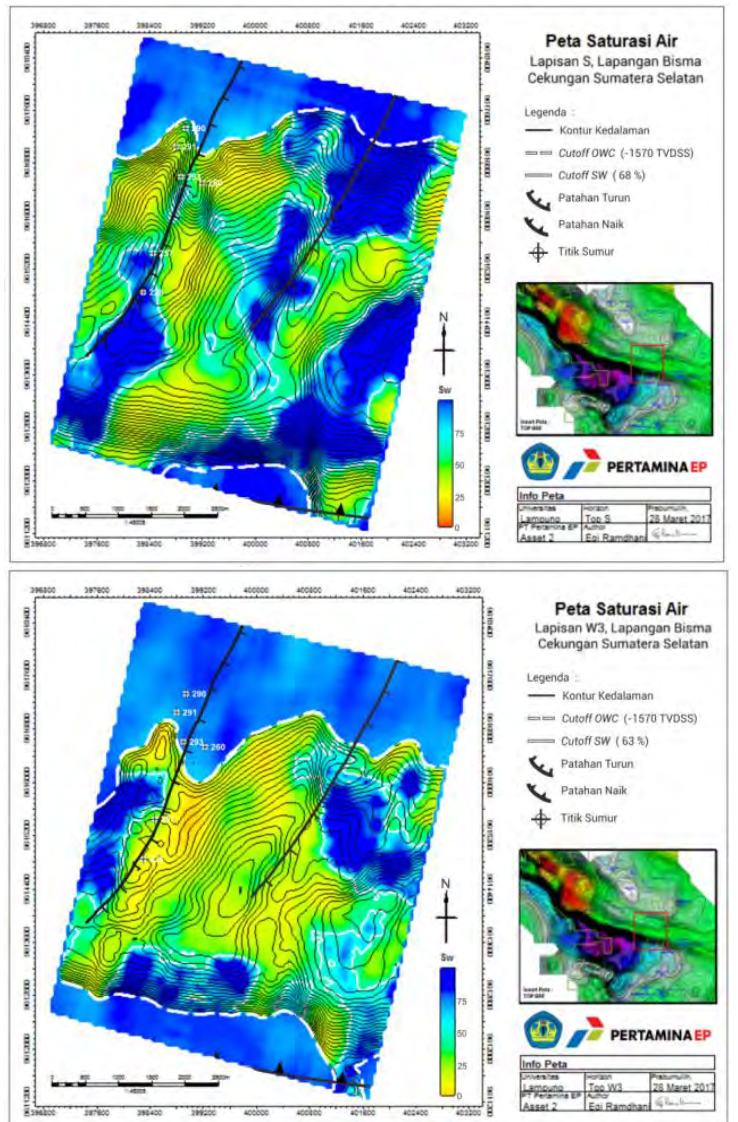

Gambar 22. Peta sebaran $S w$ lapisan S dan W3

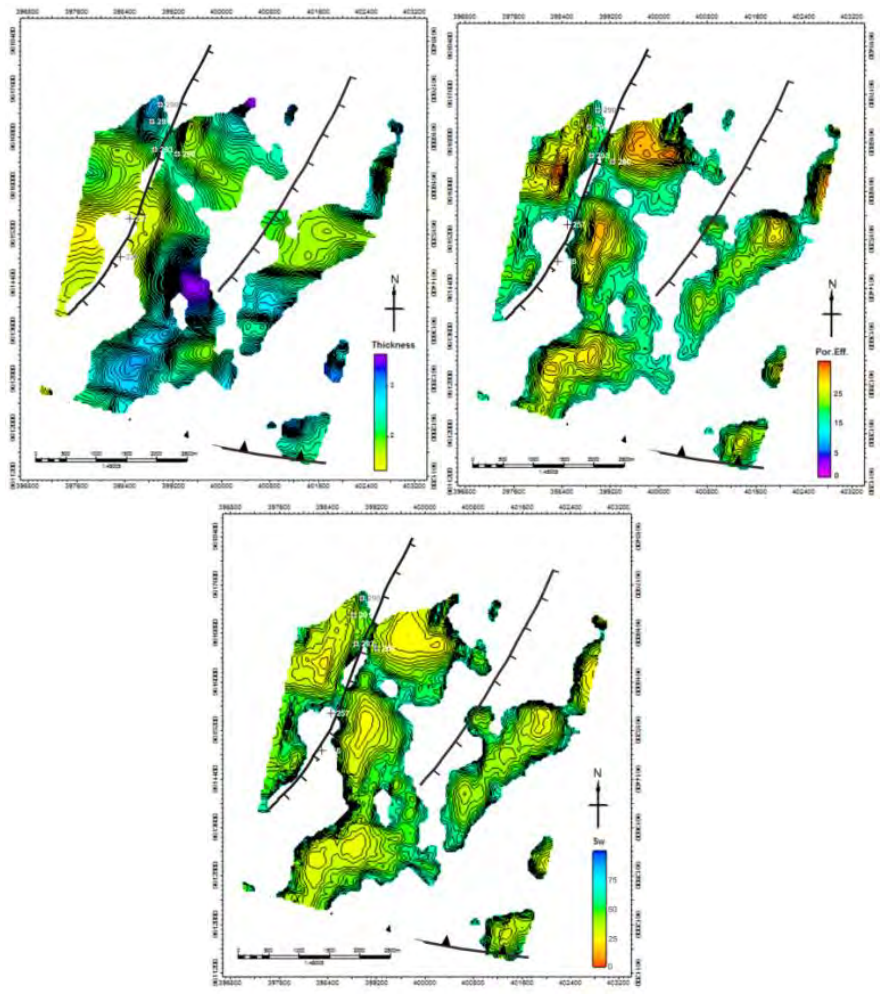

Gambar 23. Peta pay (hasil cutting) lapisan S 

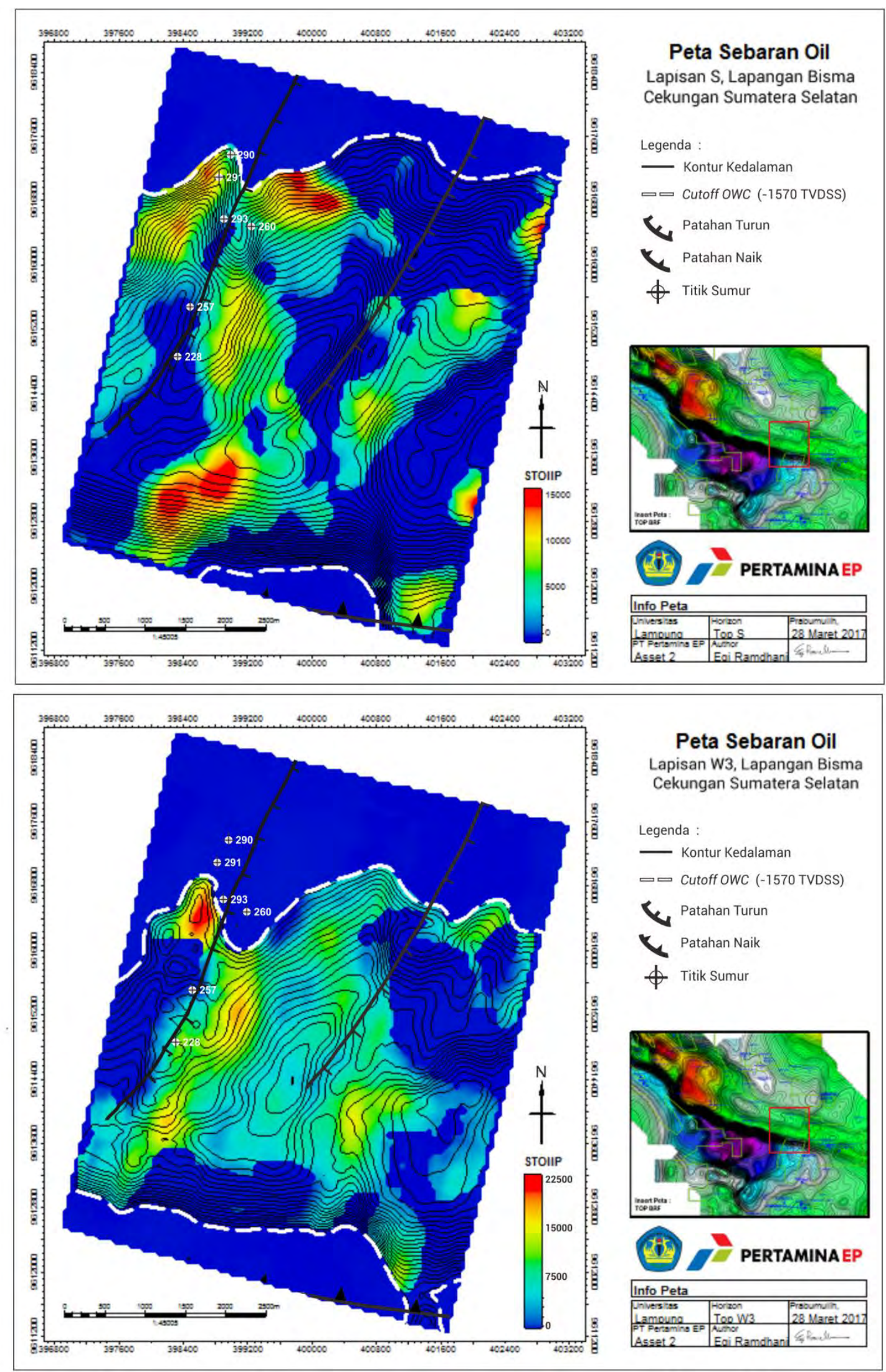

Gambar 24. Peta cadangan minyak lapisan S dan W3 Lapangan Bisma 